\title{
Diversity of native rhizobia isolated in south Brazil and their growth promotion effect on white clover (Trifolium repens) and rice (Oryza sativa) plants
}

\author{
Camille E. Granada $\cdot$ Letícia Arruda $\cdot$ Bruno Brito Lisboa • \\ Luciane M. P. Passaglia • Luciano K. Vargas
}

Received: 5 April 2013 /Revised: 28 June 2013 / Accepted: 11 July 2013 / Published online: 31 July 2013

(C) Springer-Verlag Berlin Heidelberg 2013

\begin{abstract}
In this study, rhizobia strains isolated from white clover (Trifolium repens) root nodules were evaluated in an effort to identify an efficient nitrogen-fixing rhizobia strain that can also improve the growth of rice plants (Oryza sativa). White clover plants were collected from seven sites in south Brazil, and 78 native rhizobia isolates were obtained. The genetic diversity analysis of those isolates was carried out by BOX-polymerase chain reaction. Overall, the native rhizobia isolated showed a high genetic diversity, but when the bacterial isolates from the same site were compared, the diversity was lower. One native rhizobia, POA3 (isolated from the Porto Alegre locality), was able to promote the growth of both plants and is therefore a good candidate for new inoculant formulation. Finally, we can conclude that the community of native rhizobia symbiont of white clover plants in southern Brazil is highly diverse and the growth promotion effect of rhizobia inoculation on rice plants was more pronounced in a poor nutrient substrate condition than in a rich nutrient substrate condition.
\end{abstract}

Keywords Plant growth-promoting bacteria $\cdot$ Rhizobia . Diversity

\section{Introduction}

Rhizobia species are considered legume endosymbionts as they can promote plant growth through biological nitrogen

\footnotetext{
C. E. Granada • L. M. P. Passaglia $(\bowtie)$

Departamento de Genética, Instituto de Biociências, Universidade Federal do Rio Grande do Sul (UFRGS), Av. Bento Gonçalves, 9500, Caixa Postal 15.053, 91501-970 Porto Alegre, RS, Brazil e-mail: luciane.passaglia@ufrgs.br
}

L. Arruda $\cdot$ B. B. Lisboa $\cdot$ L. K. Vargas

Fundação Estadual de Pesquisa Agropecuária (FEPAGRO), Rua

Gonçalves Dias 570, 90130-060 Porto Alegre, RS, Brazil fixation, the production of hormones and enzymes, and the solubilization of soil nutrients (Schloter et al. 1997; Vargas et al. 2009). Strains belonging to several species of the rhizobia genera have previously been isolated from the root nodules of leguminous plants (Zhang et al. 1991; Wang et al. 2010). However, a large number of native microbial population studies also include rhizobia species in the bulk soil and rhizosphere of non-leguminous plants (Ambrosini et al. 2012; Arruda et al. 2012; Farina et al. 2012; Souza et al. 2012).

In leguminous plants, the biological fixation of nitrogen performed by rhizobia species can supply all the $\mathrm{N}$ necessary for plant development (Giller and Cadisch 1995). In addition, it has been shown that the use of mixed cultures such as leguminous plants and grasses can transfer the fixed $\mathrm{N}$ from leguminous plants to these associated grasses (Nesheim and Boller 1991; Ledgard and Steele 1992; Giller and Cadisch 1995) including rice (Cho et al. 2003). In a study of clover cultivars, Ledgard (1991) demonstrated that the average amount of fixed $\mathrm{N}$ in these clover plants was $269 \mathrm{~kg} \mathrm{~N} \mathrm{ha}^{-1}$, and approximately $130 \mathrm{~kg} \mathrm{~N} \mathrm{ha}^{-1}$ of that amount was transferred to ryegrass.

Rice is one of the most important cereals in the world and the main dietary component of $20 \%$ of the world's population (IRRI and AfricaRice 2010; Seck et al. 2012). Rhizobia strains that belong to different genera are able to establish endophytic relationships with rice plants (Prayitno et al. 1999; Biswas et al. 2000a, b; Peng et al. 2002) and to promote shoot growth and enhance grain production (Mia and Shamsuddin 2010; Costa et al. 2013). Cho et al. (2003) reported that white clover cultivated prior to rice in a notillage system produced nearly sufficient levels of $\mathrm{N}$ for rice cultivation and only other deficient minerals needed to be applied.

A wide range of microorganisms are involved in important soil functions, and studies that determine the genetic diversity of soil populations are critical to understanding the 
quality and health of the soil. These microorganisms are involved in processes as soil structure formation; decomposition of organic matter; toxin removal; and the cycling of C, N, P, and S (Garbeva et al. 2004). Intraspecific variations in the soil bacterial diversity are affected by the site to be sampled, climatic changes (Handley et al. 1998), nutrient limits (Caballero-Mellado and Martinez-Romero 1999) and the host plant itself (van der Heijden et al. 2008). These variations have been evaluated by molecular methods including the polymerase chain reaction (PCR) that uses repetitive sequences such as BOX, REP, and ERIC to analyze genetic variations among different rhizobia isolates (Duodu et al. 2006).

In this study, the genetic diversity of rhizobia strains isolated from white clover root nodules was evaluated in order to identify an efficient nitrogen-fixing rhizobium strain that can also improve the growth of rice plants (Oryza sativa). We decided to work with white clover plants because this plant is one of the few winter legumes that grow in lowland soils between two rice crops. The innovative aspect of this work was the identification of a rhizobium strain that could improve the growth of both white clover and tillage rice cropped in succession. This would lead a substantial reduction of $\mathrm{N}$ fertilizer inputs, thus bringing, in the future, ecological and economic benefits to both agriculture and the environment.

\section{Material and methods}

\section{Sample collection}

White clover (Trifolium repens, native variety) roots and rhizosphere soil samples were collected in seven sites of south Brazil: Cachoeirinha ( $\left.\mathrm{CCH}-29^{\circ} 56^{\prime} 50^{\prime \prime} \mathrm{S}, 5^{\circ} 1^{\prime} 30^{\prime \prime} \mathrm{W}\right)$, Dom Pedrito (DP - 30 $58^{\prime} 54^{\prime \prime} \mathrm{S}, 54^{\circ} 40^{\prime} 39^{\prime \prime} \mathrm{W}$ ), Eldorado do Sul (ELD - 30 $0^{\circ} 5^{\prime} 9^{\prime \prime} \mathrm{S}, 51^{\circ} 37^{\prime} 5^{\prime \prime} \mathrm{W}$ ), Porto Alegre (POA-30 $01^{\prime} 59^{\prime \prime}$ $\left.\mathrm{S}, 51^{\circ} 13^{\prime} 48^{\prime \prime} \mathrm{W}\right)$, Rio Grande (RG-32 $\left.39^{\prime} 45^{\prime \prime} \mathrm{S}, 52^{\circ} 41^{\prime} 50^{\prime \prime} \mathrm{W}\right)$, São Gabriel (SG-30 $20^{\prime} 38^{\prime \prime} \mathrm{S}, 54^{\circ} 20^{\prime} 31^{\prime \prime} \mathrm{W}$ ), and Vacaria $\left(\mathrm{VC}-28^{\circ} 30^{\prime} 39^{\prime \prime} \mathrm{S}, 50^{\circ} 55^{\prime} 47^{\prime \prime} \mathrm{W}\right)$. There are no reports of rhizobia inoculation in these fields. Each soil sample was collected at a depth of $20 \mathrm{~cm}$ and had a fresh weight of $1 \mathrm{~kg}$. We considered as rhizospheric soil as the soil adhering to the roots. A portion of each sample $(0.2 \mathrm{~kg})$ was analyzed to determine the organic matter $(\mathrm{OM})$ and clay contents and the $\mathrm{pH}$ value using standard methods (Sparks 1996).

Bacterial isolation from white clover root nodules

Three independent plants with adhering (rhizospheric) soil that were spaced at least $2 \mathrm{~m}$ away from each other were collected from each site. All the root nodules were removed and surface sterilized by washing them in $70 \%$ ethanol for
$1 \mathrm{~min}$, followed by a $2 \%$ sodium hypochlorite $(v / v)$ wash for $1 \mathrm{~min}$ and finally five serial washes with sterilized distilled water. Rhizobia isolation was performed according to Somasegaram and Hoben (1985). Individual colonies were cultured in yeast mannitol (YM) medium (55 mM mannitol; $3 \mathrm{mM} \mathrm{K}_{2} \mathrm{HPO}_{4} ; 0.7 \mathrm{mM} \mathrm{MgSO}{ }_{4} 7 \mathrm{H}_{2} \mathrm{O} ; 1.71 \mathrm{mM} \mathrm{NaCl}$; $0.4 \mathrm{~g} \mathrm{l}^{-1}$ of yeast extract; $\mathrm{pH} 6.8$ ) for $72 \mathrm{~h}$ at $28^{\circ} \mathrm{C}$ and stored at $-20{ }^{\circ} \mathrm{C}$ in $50 \%$ glycerol.

\section{Evaluation of plant growth promotion abilities}

Native rhizobia isolates were grown in YM medium supplemented with tryptophan $\left(2.4 \times 10^{-3} \mathrm{M}\right)$ for $72 \mathrm{~h}$ at $28^{\circ} \mathrm{C}$. The analysis of indolic compounds (ICs) production was performed according to the method of Glickmann and Dessaux (1995). Analysis of siderophores production involved the inoculation of $10 \mu \mathrm{l}$ of each bacterial culture in agar (1.5 \%) King B medium (diluted by five-fold; Glickmann and Dessaux 1995) supplemented with CAS dye (Schwyn and Neilands 1987). The evaluation of these plant growth promotion abilities was only qualitative; the rhizobia isolates were classified as producers or nonproducers of ICs and siderophores.

\section{Genetic diversity of bacterial isolates}

The DNA of native rhizobia isolates was extracted for molecular characterization either according to the method of Sambrook and Russel (2001) or using the ChargeSwitch Genomic DNA kit (Invitrogen). The DNA fragments were amplified by PCR using the enterobacterial repetitive sequence BOX A1 primer (Versalovicj et al. 1994). Reactions were performed according to Giongo et al. (2010). The resulting DNA fingerprints were transformed into a binary matrix and subjected to a diversity analysis using the UPGMA algorithm and the Jaccard coefficient using the PAST software (Hammer et al. 2001). The Shannon diversity index ( $H^{\prime}$; Shannon and Weaver 1949) was also determined. Two well-characterized rhizobia strains were included in this analysis as controls. These strains are recommended for the inoculation of white clover plants: SEMIA 222 (Rhizobium leguminosarum - Menna et al. 2006) and SEMIA 235 (Rhizobium leguminosarum -Binde et al. 2009) and were obtained from FEPAGRO (Brazil).

Selection and characterization of rhizobia isolates for plant inoculation

Seven native rhizobia isolates (POA3, SG15, EDL15, ELD18, CCH17, DP12, and VC12) displaying different plant growth-promoting abilities, in addition to the two well-characterized control rhizobia strains (SEMIA 222 and SEMIA 235), were tested in inoculation experiments of white clover (T. repens) and rice (O. sativa) plants. 
The seven selected native isolates were identified at the genera level by partial 16S rRNA gene sequencing. The DNA previously extracted from the native isolates was used to PCR amplify a partial segment of $16 \mathrm{~S}$ rDNA (approximately 450 base pairs) using the primers U968 and L1401 (Felske et al. 1997). The amplification reactions consisted of $50 \mathrm{ng}$ of DNA, $1.5 \mathrm{mM} \mathrm{MgCl}_{2}, 200 \mu \mathrm{M}$ each dNTP, $0.3 \mu \mathrm{M}$ each primer and $1 \mathrm{U}$ of Taq DNA polymerase (Invitrogen) in a final volume of $25 \mu \mathrm{l}$. The amplification conditions and PCR product visualization procedures used were previously published (Ambrosini et al. 2012). Amplified DNA fragments were sequenced in a Megabace 1000 automatic sequencer using the DYEnamic ${ }^{\mathrm{TM}}$ ET Dye Terminator Cycle Sequencing Kit (GE Health Care). Sequence analyses were performed with BioEdit version 7.0.9.0 software (Hall 1999) in order to verify their quality and to check for possible chimeric origins. The partial $16 \mathrm{~S}$ rDNA sequences were compared with sequences from the EzTaxon-e Server, which is an extension of the EzTaxon database (Chun et al. 2007, available at http://eztaxon-e.ezbiocloud.net/), and the GenBank database using BLASTN software (Altschul et al. 1997; available at http://blast.ncbi.nlm.nih.gov/). The DNA sequences obtained in this work have been deposited in the GenBank database under accession numbers KC576967 to KC576973.

\section{Greenhouse experiment with white clover plants}

The assay was conducted in Leonard jars with sterile substrate composed of vermiculite and sand (3:1) on top and Sarruge nutritive solution (diluted $25 \%$; Sarruge 1975) without $\mathrm{N}$ on bottom. Four replicates of two white clover plants (native variety - seeds were obtained from FEPAGRO) per jar were inoculated with a $5 \mathrm{ml}$ culture of one of the seven native rhizobia isolates or one of the two control rhizobia strains (SEMIA222 or SEMIA 235) grown in yeast-tryptone medium (YT; $0.5 \%$ tryptone, $0.3 \%$ yeast extract, $2.7 \mathrm{mM}$ $\mathrm{CaCl} ; \mathrm{pH}$ 6.8). Two control treatments were performed: one without $\mathrm{N}$ (negative control $=\mathrm{T}-$ ) and the other with $30 \mathrm{mg}$ of $\mathrm{N}$ as $\mathrm{NH}_{4} \mathrm{NO}_{3}$ per jar (positive control $=\mathrm{T}+$ ). After 120 days of growth, the plants were harvested and dried at $60{ }^{\circ} \mathrm{C}$ until they reached a constant weight and the shoot dry matter and the amount of $\mathrm{N}$ accumulated in shoots were estimated. Statistical analyses were performed using an ANOVA test, with the means compared by the Scott-Knott test $(P<0.01)$ in the Assistat 7.6 beta program (available in www.assistat.com).

Analysis of rice germination following rhizobia inoculation

Rice seeds (variety IRGA 422, obtained from FEPAGRO) were surface sterilized by washing them in $70 \%$ ethanol for $2 \mathrm{~min}$, followed by a $2 \%$ sodium hypochlorite $(v / v)$ wash for $2 \mathrm{~min}$ and finally five serial washes with sterilized distilled water. A standard germination test was then performed on the seeds (ISTA 1996). Five germination boxes were used per treatment. In each box, 50 rice seeds were placed on top of two sheets of germination paper and the paper sheets were moistened with either $15 \mathrm{ml}$ of a single rhizobia isolate culture grown in sterile YT medium or with YT medium alone as a control treatment. This germination test was conducted for 12 days, and the speed of germination index was evaluated (Maguire 1962). On the 12th day, ten seedlings from each box (50 seedlings per treatment) were collected to determine the root and shoot lengths and were dried at $60{ }^{\circ} \mathrm{C}$ and weighed (10 seedlings). Statistical analyses were performed using an ANOVA test, with the means compared using the Scott-Knott test $(P<0.01)$ in the Assistat 7.6 beta program.

Rice growth promotion by the rhizobia isolates in greenhouse experiments

The effect of rhizobia inoculation on the growth promotion of rice plants was analyzed in both a non sterile and a sterile substrate. Rice seeds (variety IRGA 422) were imbedded for $48 \mathrm{~h}$ in YT medium containing $10^{8}$ rhizobial cells ml${ }^{-1}$ and in a sterile YT medium for the control treatment prior to planting in the two substrates. The sterile substrate experiment was conducted in Leonard jars with vermiculite and sand as described above. The non sterile substrate experiment was conducted in $700 \mathrm{ml}$ pots filled with Plantmax ${ }^{\circledR}$ substrate (1,576 mg P kg of soil ${ }^{-1}, 1,428 \mathrm{mg} \mathrm{K} \mathrm{kg}$ of soil ${ }^{-1}, 22.9 \mathrm{mg}$ $\mathrm{Ca} \mathrm{kg} \mathrm{of} \mathrm{soil}^{-1}, 8.6 \mathrm{mg} \mathrm{Mg} \mathrm{kg}$ of soil ${ }^{-1}, \mathrm{pH}=5.47$ ). Two rice seeds were planted in each pot or jar. In the sterile substrate experiment, all plants were fertilized with $35 \mathrm{mg}$ of $\mathrm{N}$ (in the form of $\mathrm{NH}_{4} \mathrm{NO}_{3}$ ) and Sarruge nutrient solution (diluted $25 \%$; Sarruge 1975). The experiments were conducted for 25 days after plant emergence, after this time the plants were harvested and dried at $60{ }^{\circ} \mathrm{C}$ until they reached a constant weight. Then, the dry weights of the roots and shoots were determined. Statistical analysis was performed using an ANOVA test, with the means compared using Tukey's test $(P<0.01)$ in the Assistat 7.6 beta program.

\section{Results}

Diversity of native rhizobia isolates

Samples of the rhizospheric soil and the roots of white clover plants were collected in seven different regions in south Brazil. The $\mathrm{OM}$ and clay contents and $\mathrm{pH}$ value for each soil sample studied are shown in Table 1. Soil samples from Eldorado do Sul contained the lowest percentage of organic matter content (2.1), followed by samples from Rio Grande (2.4) and São Gabriel (2.8); samples from Vacaria are 
Table 1 Clay, organic matter content, and $\mathrm{pH}$ of soils from the seven localities studied

\begin{tabular}{lccc}
\hline Sampling site & $\begin{array}{l}\text { Clay } \\
\%\end{array}$ & $\begin{array}{l}\text { OM } \\
\%\end{array}$ & $\mathrm{pH}$ \\
\hline Cachoeirinha (CCH) & 32 & 3.3 & 6.3 \\
Dom Pedrito (DP) & 32 & 3.2 & 5.6 \\
Eldorado do Sul (ELD) & 22 & 2.1 & 5.0 \\
Porto Alegre (POA) & 35 & 3.2 & 6.3 \\
Rio Grande (RG) & 9 & 2.4 & 8.1 \\
São Gabriel (SG) & 12 & 2.8 & 5.6 \\
Vacaria (VC) & 16 & 6.4 & 5.8 \\
\hline
\end{tabular}

$O M$ organic matter

highlighted for their high percentage of organic matter (6.4). Soil samples from Rio Grande, São Gabriel, and Vacaria contained the lowest percentage of clay $(9,12$, and 16, respectively), whereas soil samples from Cachoeirinha and Dom Pedrito contained the highest clay content percentage (32 for both). In addition to low clay content, the Rio Grande samples were also the most alkaline ( $\mathrm{pH} 8.1)$. The remaining soil samples had a moderately acidic $\mathrm{pH}$ that is good for both nutrient availability and bacterial growth.

A total of 78 native rhizobia isolates were obtained from white clover root nodules. Investigation of their plant growth-promoting (PGP) abilities (Table 2) demonstrated that $25.6 \%$ of all rhizobia isolates were able to produce indolic compounds including approximately $95 \%$ of the isolates from Eldorado do Sul locality. The evaluation of siderophores production showed that only $7.7 \%$ of all native rhizobia isolates were able to produce these compounds. The soil from Cachoeirinha showed the greatest number $(25 \%)$ of siderophores producers.

The genetic diversity was determined by variations in the bacterial repetitive sequences using the PCR-BOX approach. We analyzed 78 native rhizobia isolates from the seven sites studied as well as two control rhizobia strains recommended for the white clover inoculation (SEMIA 222 and SEMIA 235). According to the Shannon diversity index ( $H^{\prime}$; Table 2$)$, the rhizobia communities isolated from Cachoeirinha $\left(H^{\prime}=2.60\right)$ and Vacaria $\left(H^{\prime}=2.61\right)$ have the highest diversity indices, while those isolated from São Gabriel $\left(H^{\prime}=2.06\right)$ and Dom Pedrito $\left(H^{\prime}=2.07\right)$ have intermediate diversity indices. Less diverse rhizobia communities were isolated from Porto Alegre $\left(H^{\prime}=1.16\right)$, Rio Grande $\left(H^{\prime}=1.03\right)$, and Eldorado do Sul $\left(H^{\prime}=0.29\right)$. The dendrogram of similarity (Fig. 1) indicates that the native rhizobia isolates collected in this study are highly diverse. Rhizobia strain SEMIA 222 was less than $30 \%$ similar to the native rhizobia group composed of isolates POA1, VC8, and CCH11. The other wellcharacterized rhizobia strain, SEMIA 235, was less than $30 \%$ similar to the native rhizobia group composed of isolates RG1 and RG18. Groups with more than $70 \%$ similarity were always composed of bacterial isolates from the same sampling site; for example, the group composed of native rhizobia isolates POA3, POA10, POA8, and POA9. All of these strains were isolated from the Porto Alegre locality.

The correlation of the soil organic matter and clay content, soil $\mathrm{pH}$ and bacterial diversity was investigated using principal component analysis (PCA; Fig. 2). The first two dimensions of the PCA explained $65.2 \%$ of the total variation; principal component 1 (PC1) accounted for $36.9 \%$ of the variance, and principal component 2 (PC2) accounted for $28.4 \%$ of the variance. Soil organic matter content was significantly $(P<0.01)$ correlated with genetic diversity $\left(H^{\prime}\right)$; samples from $\mathrm{VC}$ and $\mathrm{CCH}$ displayed the highest diversity indices and the highest soil organic matter contents (6.4 and 3.3, respectively). The highly alkaline soil from the RG samples $(\mathrm{pH}=8.1)$, and the high acidic soil from the ELD samples $(\mathrm{pH}=5.0)$ were negatively correlated with genetic diversity.

Growth promotion of white clover and rice by the selected rhizobia isolates

Seven different rhizobia isolates were selected for greenhouse experiments (POA3, DP12, ELD15, ELD 18, CCH17, SG15, and VC12). Two PGP characteristics of these native rhizobia (siderophores and indolic compound production) were investi-
Table 2 Number of rhizobia isolates, siderophores and indolic compound (IC) producers and the Shannon diversity index $\left(H^{\prime}\right)$ at each sample site

\begin{tabular}{lcccc}
\hline Sampling sites & Number of isolates & $H^{\prime}$ & Siderophore producers & IC Producers \\
\hline Cachoeirinha (CCH) & 16 & 2.60 & 4 & 1 \\
Dom Pedrito (DP) & 8 & 2.07 & 0 & 2 \\
Eldorado do Sul (ELD) & 12 & 0.29 & 1 & 11 \\
Porto Alegre (POA) & 11 & 1.16 & 1 & 2 \\
Rio Grande (RG) & 14 & 1.03 & 0 & 1 \\
São Gabriel (SG) & 12 & 2.06 & 0 & 3 \\
Vacaria (VAC) & 5 & 2.61 & 0 & 0 \\
\hline
\end{tabular}




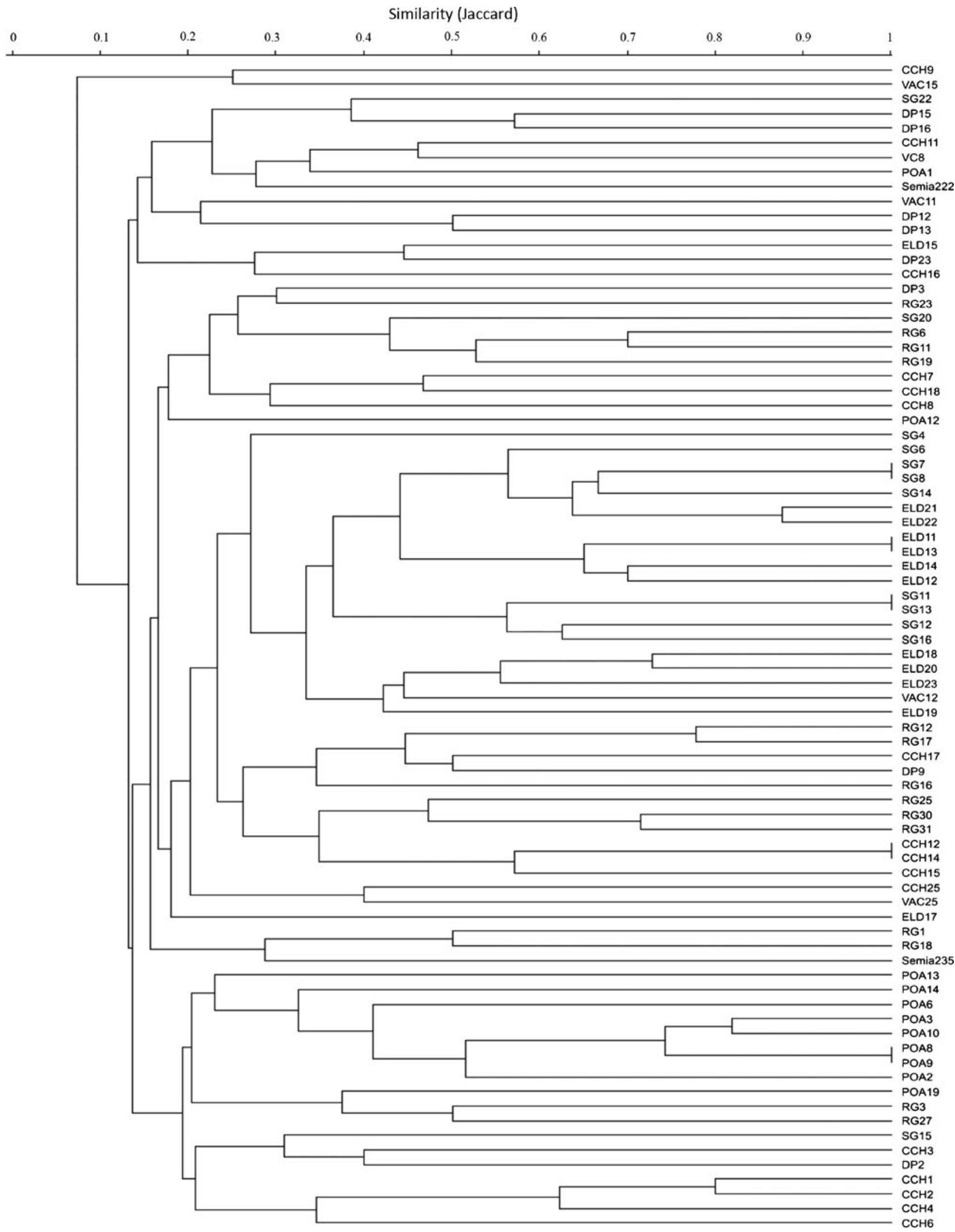

Fig. 1 Dendrogram of genetic similarity based on UPGMA cluster analysis using the Jaccard coefficient (PAST software). The data obtained by PCR-BOX from 78 rhizobia isolates from Porto Alegre
$(P O A)$, Eldorado do Sul $(E L D)$, Vacaria $(V C)$, Dom Pedrito $(D P)$, Cachoeirinha $(\mathrm{CCH})$ and São Gabriel $(\mathrm{SG})$ and two strains recommended for inoculation in white clover, SEMIA 222 and SEMIA 235 
Fig. 2 Principal component analysis (PCA) of the diversity index $\left(H^{\prime}\right)$, soil organic matter $(O M)$, and clay percentages and soil $\mathrm{pH}$ value determined from the soil samples: Porto Alegre $(P O A)$, Eldorado do Sul (ELD), Vacaria $(V C)$, Dom Pedrito $(D P)$, Cachoeirinha $(\mathrm{CCH})$, and São Gabriel $(S G)$. Principal component 1 ( $P C 1)$ accounted for $36.9 \%$ of the total variation, and principal component 2 (PC2) accounted for $28.4 \%$

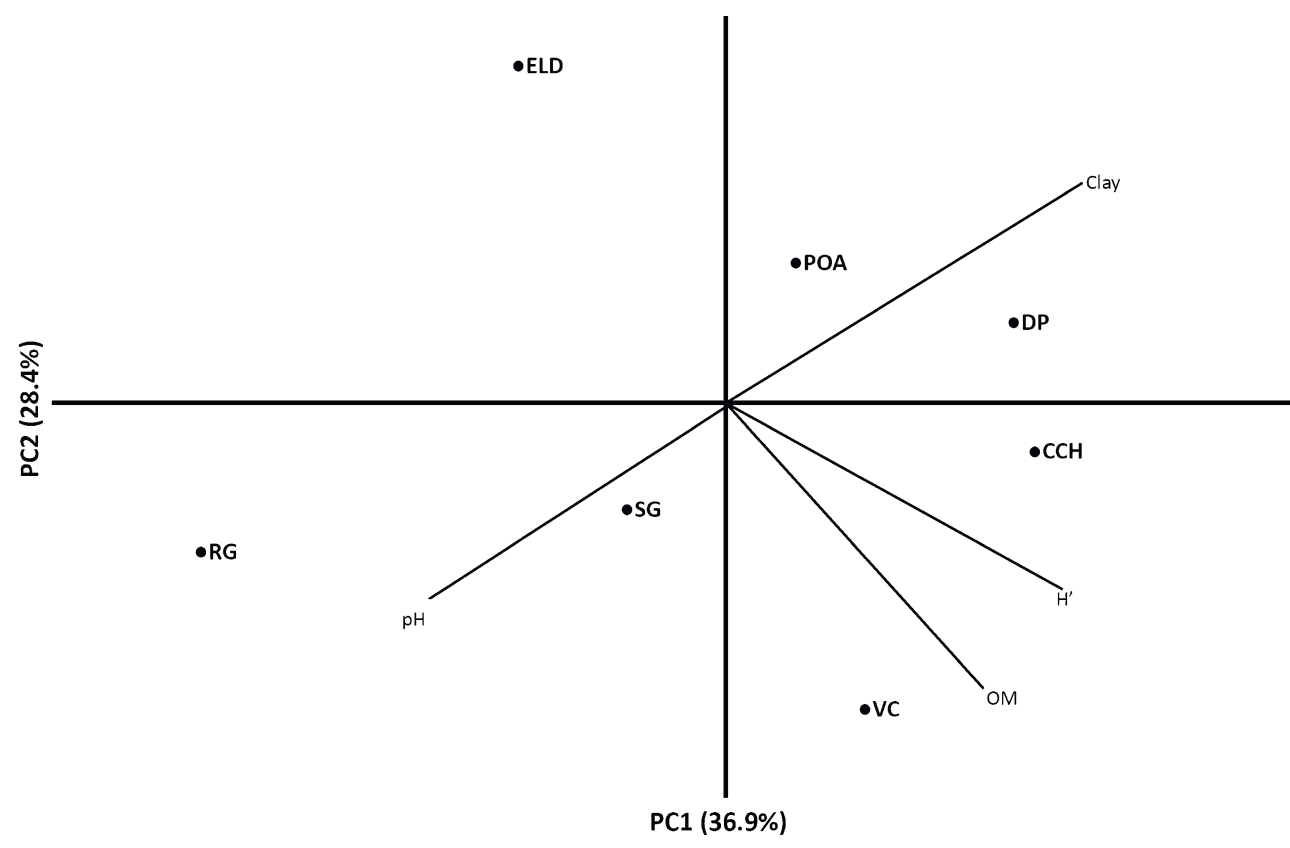

gated (Table 3). The seven native rhizobia selected for this experiment displayed different PGP abilities: three of them produced siderophores (POA3, ELD15, and CCH17); and three were able to produce indolic compounds (ELD15, DP12, and SG15). The rhizobium isolate ELD15 presented the two PGP characteristics analyzed, and the isolates ELD18 and VC12 did not present any of them.

The analyses of the shoot dry matter and the amount of $\mathrm{N}$ accumulated in the shoots of white clover plants grown in greenhouse and inoculated with one of the seven selected isolates or with one of the two control strains (SEMIA 222 and SEMIA 235) are shown in Table 4. The native isolate POA3 (Rhizobium sp.) and the control strains SEMIA 222 and SEMIA 235 presented the highest shoot dry matter and the highest amount of $\mathrm{N}$ accumulated in the shoot; these

Table 3 Rhizobia isolates chosen for growth promotion experiments of white clover and rice plants

\begin{tabular}{llcc}
\hline Rhizobia isolate $^{\mathrm{a}}$ & Identification & $\begin{array}{l}\text { Siderophore } \\
\text { production }\end{array}$ & $\begin{array}{l}\text { Indolic compound } \\
\text { (IC) production }\end{array}$ \\
\hline POA3 & Rhizobium sp. & + & - \\
DP12 & Rhizobium sp. & - & + \\
ELD15 & Rhizobium sp. & + & + \\
ELD18 & Rhizobium sp. & - & - \\
CCH17 & Rhizobium sp. & + & - \\
SG15 & Rhizobium sp. & - & + \\
VC12 & Rhizobium sp. & - & - \\
\hline
\end{tabular}

${ }^{\text {a }}$ Rhizobia isolate from: $P O A$ Porto Alegre, ELD Eldorado do Sul, $V C$ Vacaria, DP Dom Pedrito, $C C H$ Cachoeirinha and $S G$ São Gabriel; + bacterial isolate positive for siderophores or IC production; - bacterial isolate negative for siderophores or IC production measurements were even greater than those presented by the positive control condition $(\mathrm{T}+)$.

All the seven native rhizobia isolates selected were able to improve the rice seed germination speed as determined by germination tests (Table 5). Seedlings inoculated with isolate POA3 had the longest root length, whereas seedlings inoculated with isolate ELD18 had the longest shoot length and the highest seedling dry matter.

Greenhouse studies on rice plants grown in a sterile substrate (Table 6) indicated that plants inoculated with isolates POA3, SG15, and SEMIA235 presented the best values of shoot dry matter. Data from root dry matter did not present significant differences amongst the native rhizobia, SEMIA strains, and control treatments. When rice plants were grown in a non sterile substrate they presented a substantially higher shoot and root dry matters. This fact could be attributed to the elevated nutrient content in the Plantmax ${ }^{\circledR}$ substrate (see "Material and methods"). In this experiment, plants inoculated with native rhizobia POA3 and DP12 demonstrated the highest values for shoot and root dry matters, being statistically similar to data obtained for the positive control treatment (Table 6).

Taken together, the results obtained with the inoculation experiments in both white clover and rice plants indicated that the isolate POA3 (isolated from the Porto Alegre locality) was able to promote the growth of both plants and is therefore a good candidate for a new inoculant formulation. Probably, the abilities of $\mathrm{N}$ fixation and siderophores production displayed by POA3 contributed for the results observed with this strain, although we cannot ruled out that other characteristics not evaluated in this work could also contributed for the plant growth promotion. Rice plants grown in the nutrient rich Plantmax substrate indicate that 
Table 4 Shoot dry matter and nitrogen $(\mathrm{N})$ accumulated in white clover plants inoculated with different rhizobia isolates and grown for 120 days in greenhouse conditions

\begin{tabular}{lcc}
\hline Treatment $^{\mathrm{a}}$ & $\begin{array}{l}\text { Shoot dry matter } \\
\text { mg plants }^{-1}\end{array}$ & N accumulated in the shoot \\
\hline T- & $415 \pm 64 \mathrm{~d}$ & $6.4 \pm 0.6 \mathrm{c}$ \\
POA3 & $3760 \pm 264 \mathrm{a}$ & $225.5 \pm 35.5 \mathrm{a}$ \\
DP12 & $1783 \pm 183 \mathrm{c}$ & $35.7 \pm 7.6 \mathrm{c}$ \\
ELD15 & $3123 \pm 235 \mathrm{~b}$ & $113.3 \pm 18.3 \mathrm{~b}$ \\
ELD18 & $448 \pm 74 \mathrm{~d}$ & $8.5 \pm 1.6 \mathrm{c}$ \\
CCH17 & $1855 \pm 151 \mathrm{c}$ & $52.9 \pm 3.8 \mathrm{c}$ \\
SG15 & $385 \pm 65 \mathrm{~d}$ & $4.3 \pm 2.1 \mathrm{c}$ \\
VC12 & $1667 \pm 290 \mathrm{c}$ & $40.0 \pm 3.5 \mathrm{c}$ \\
SEMIA 222 & $3886 \pm 258 \mathrm{a}$ & $226.4 \pm 31.4 \mathrm{a}$ \\
SEMIA 235 & $4267 \pm 351 \mathrm{a}$ & $259.4 \pm 53.2 \mathrm{a}$ \\
T+ & $3296 \pm 282 \mathrm{~b}$ & $79.5 \pm 5.4 \mathrm{~b}$ \\
\hline
\end{tabular}

${ }^{a}$ Rhizobia isolate from: $P O A$ Porto Alegre, ELD Eldorado do Sul, $V C$ Vacaria, $D P$ Dom Pedrito, $C C H$ Cachoeirinha, and $S G$ São Gabriel. The means followed by different letters differ by using the Scott-Knott test $(P<0.01) . T-$ control treatment without nitrogen fertilization; $T+$ control treatment with $30 \mathrm{mg}$ of $\mathrm{N}$ (as $\mathrm{NH}_{4} \mathrm{NO}_{3}$ ) per pot. The assay was conducted in Leonard jars with sterile substrate composed of vermiculite and sand (3:1) on top and Sarruge nutritive solution (diluted $25 \%$; Sarruge 1975) without N on bottom

rhizobium inoculation had no effect on plant growth promotion in this nutrient rich condition.

\section{Discussion}

The composition of microbial communities is influenced by the physico-chemical properties of the soil (Nannipieri et al. 2003; Chaparro et al. 2012; Meliani et al. 2012). Host plants can influence the presence or absence of specific strains of Rhizobium sp. and thus affect their diversity (Kennedy 1999). We reported a low genetic similarity (and consequently a high genetic diversity) in all the investigated rhizobia isolates from white clover, but among the rhizobia isolated from the same site, the genetic similarity was high (Fig. 1). The interaction of the plants and soil types is directly related to bacterial diversity, and this interaction might select the microbial populations (Garbeva et al. 2004). This study demonstrates that the genetic diversity indices of native rhizobia are strongly correlated with the organic matter content of soil (Fig. 2). In a similar study, the high genetic diversity of Bradyrhizobium sp. isolated from soybean plants in no-tillage soils was directly related to high organic matter content (Ferreira et al. 2000). Nannipieri et al. (2003) reported that the microbial diversity of surface soil is based on the presence of a large variety and content of organic compounds.

Bacterial isolates from the same microbial species can be evaluated for intraspecific diversity based on the analysis of repetitive nucleotide sequences, including the $\mathrm{BOX}$ motif $(\mathrm{Li}$ et al. 2009). The high genetic diversity found in this work can be attributed to spatial separation, but other factors can influence the genetic diversity, such as environmental differences and host-bacterial interactions (Schloter et al. 1997). The evaluation of intraspecific diversity by the repetitive sequences found that spatial separation is a very important factor for bacterial variability in several other species: Bradyrhizobium sp. and Glycine max (Giongo et al. 2008); Acidovorax citrulli, Cucumis melo, and Citrullus lanatus plants (Alves et al. 2010).

The symbiotic rhizobia isolated from leguminous plants can promote plant growth not only through their biological $\mathrm{N}$ fixation ability (in leguminous plants) but also via their inherent PGP capacities: siderophores and indolic compound production and nutrient solubilization (Vargas et al. 2009; Souza et al. 2012; Ashraf et al. 2013). This study indicated that the PGP ability most common among all isolates was indolic compounds production. These results agree with those obtained by Dubey et al. (2010), who found that indolic compounds

Table 5 Sterile experiment of bacterial inoculation in rice seeds to evaluate the germination and vigor of seedlings

\begin{tabular}{lcccc}
\hline Bacterial isolates $^{\mathrm{a}}$ & SGI & Length of roots $(\mathrm{mm})$ & Length of shoots $(\mathrm{mm})$ & Seedling dry matter $(\mathrm{mg})$ \\
\hline Control & $17.0 \pm 1.7 \mathrm{~b}$ & $40.1 \pm 6.4 \mathrm{c}$ & $28.3 \pm 4.2 \mathrm{e}$ & $30.4 \pm 1.8 \mathrm{~b}$ \\
POA3 & $22.3 \pm 3.6 \mathrm{a}$ & $93.6 \pm 7.6 \mathrm{a}$ & $41.1 \pm 6.9 \mathrm{c}$ & $38.0 \pm 2.5 \mathrm{~b}$ \\
DP12 & $21.6 \pm 2.5 \mathrm{a}$ & $36.7 \pm 14.3 \mathrm{c}$ & $39.2 \pm 9.9 \mathrm{c}$ & $33.8 \pm 11.1 \mathrm{~b}$ \\
ELD15 & $24.3 \pm 1.1 \mathrm{a}$ & $46.6 \pm 9.2 \mathrm{~b}$ & $43.7 \pm 11.7 \mathrm{c}$ & $36.6 \pm 4.7 \mathrm{~b}$ \\
ELD18 & $21.6 \pm 1.2 \mathrm{a}$ & $54.4 \pm 8.8 \mathrm{~b}$ & $59.4 \pm 10.3 \mathrm{a}$ & $47.4 \pm 1.1 \mathrm{a}$ \\
CCH17 & $24.0 \pm 0.7 \mathrm{a}$ & $44.0 \pm 7.3 \mathrm{~b}$ & $36.1 \pm 18.0 \mathrm{~d}$ & $41.1 \pm 3.5 \mathrm{a}$ \\
SG15 & $21.6 \pm 1.1 \mathrm{a}$ & $37.5 \pm 13.2 \mathrm{c}$ & $40.2 \pm 9.7 \mathrm{c}$ & $33.6 \pm 6.3 \mathrm{~b}$ \\
VC12 & $22.1 \pm 3.0 \mathrm{a}$ & $34.0 \pm 5.1 \mathrm{c}$ & $46.8 \pm 8.9 \mathrm{c}$ & $34.6 \pm 3.7 \mathrm{~b}$ \\
\hline
\end{tabular}

${ }^{\text {a }} S G I$ Speed of germination. Rhizobial isolate from: $P O A$ Porto Alegre, $E L D$ Eldorado do Sul, $V C$ Vacaria, $D P$ Dom Pedrito, $C C H$ Cachoeirinha, and $S G$ São Gabriel. The means (10 seeds $\times 5$ repetitions) followed by different letters differ by using the Scott-Knott test $(P<0.01)$. In the control treatment, paper sheets were moistened with $15 \mathrm{ml}$ of sterile YT medium 
Table 6 Shoot and root dry matter of rice plants inoculated with different rhizobia isolates and strains grown in both sterile and non sterile substrates for 25 days in greenhouse conditions

\begin{tabular}{|c|c|c|c|c|}
\hline \multirow[t]{2}{*}{ Bacterial isolates $^{\mathrm{a}}$} & \multicolumn{2}{|l|}{ Sterile substrate } & \multicolumn{2}{|l|}{ Non sterile substrate } \\
\hline & $\begin{array}{l}\text { Shoot dry matter } \\
\text { mg plant }^{-1}\end{array}$ & Root dry matter & Shoot dry matter & Root dry matter \\
\hline POA3 & $232.00 \pm 34.0 \mathrm{a}$ & $79.33 \pm 47.0 \mathrm{a}$ & $1312.00 \pm 91.8 \mathrm{a}$ & $451.00 \pm 34.7 \mathrm{a}$ \\
\hline DP12 & $162.33 \pm 4.7 \mathrm{~b}$ & $62.36 \pm 2.3 \mathrm{a}$ & $1238.66 \pm 18.5 \mathrm{a}$ & $440.33 \pm 20.8 \mathrm{a}$ \\
\hline ELD15 & $174.66 \pm 8.7 \mathrm{ab}$ & $70.66 \pm 27.6 \mathrm{a}$ & $550.33 \pm 124.8 \mathrm{c}$ & $246.33 \pm 18.6 \mathrm{~cd}$ \\
\hline ELD18 & $152.33 \pm 13.4 \mathrm{~b}$ & $71.00 \pm 2.6 \mathrm{a}$ & $987.66 \pm 65.0 \mathrm{ab}$ & $379.32 \pm 29.5 \mathrm{abc}$ \\
\hline $\mathrm{CCH} 17$ & $193.00 \pm 2.0 \mathrm{ab}$ & $78.36 \pm 1.5 \mathrm{a}$ & $749.66 \pm 35.0 \mathrm{bc}$ & $236.33 \pm 20.1 \mathrm{~cd}$ \\
\hline SG15 & $225.33 \pm 7.6 \mathrm{a}$ & $95.66 \pm 13.5 \mathrm{a}$ & $622.00 \pm 89.0 \mathrm{bc}$ & $318.33 \pm 37.1 \mathrm{abcd}$ \\
\hline $\mathrm{VC} 12$ & $140.33 \pm 16.3 \mathrm{bc}$ & $53.33 \pm 13.3 \mathrm{a}$ & $879.00 \pm 88.0 \mathrm{ab}$ & $328.00 \pm 47.1 \mathrm{abcd}$ \\
\hline SEMIA 222 & $175.00 \pm 7.9 \mathrm{ab}$ & $71.33 \pm 14.2 \mathrm{a}$ & $754.00 \pm 230.5 \mathrm{bc}$ & $384.66 \pm 41.1 \mathrm{abc}$ \\
\hline SEMIA 235 & $230.33 \pm 46.9 \mathrm{a}$ & $86.66 \pm 46.8 \mathrm{a}$ & $683.00 \pm 63.2 \mathrm{bc}$ & $188.66 \pm 19.6 \mathrm{~d}$ \\
\hline Control & $162.33 \pm 20.8 \mathrm{~b}$ & $56.66 \pm 21.0 \mathrm{a}$ & $863.33 \pm 78.1 \mathrm{abc}$ & $450.66 \pm 41.2 \mathrm{a}$ \\
\hline
\end{tabular}

Means followed by different letters differ using Tukey's test $(P<0.01)$

${ }^{a}$ Rhizobial isolate from: $P O A$ Porto Alegre, ELD Eldorado do Sul, $V C$ Vacaria, DP Dom Pedrito, $C C H$ Cachoeirinha, and $S G$ São Gabriel. Each treatment was composed by three replicates in both experiments. In sterile substrate, the control treatment and the inoculated treatments were fertilized with $35 \mathrm{mg}$ of $\mathrm{N}$ (as $\mathrm{NH}_{4} \mathrm{NO}_{3}$ ) and Sarruge's nutrient solution (diluted $25 \%$ ). The non sterile substrate control treatment and all the inoculated treatments were moistened only with water

production was the most common characteristic of the rhizobia species isolated from Cajanus cajan; however, the results disagree with those obtained by Antoun et al. (1998), who found that siderophores production was the most common PGP characteristic in rhizobia isolates from different leguminous plants. These data reinforce the proposal that the diversity of PGP characteristics displayed by the bacterial isolates also varies according to the soil type and host plant (Akers 1983; Hu et al. 2009; Laheurte and Berthelin 1988; Rodríguez and Fraga 1999; Sundara et al. 2002; Costa et al. 2013).

The biological $\mathrm{N}$ fixation performed by rhizobia species has been demonstrated to supply all the $\mathrm{N}$ necessary for leguminous development (Zahran 1999) of several host plants: faba beans (Beck and Duc 1991; Delgado et al. 1994), peanuts (Raverkar and Konde 1988; Jonah et al. 2012), soybean (Delgado et al. 1994; Masson-Boivin et al. 2009; Giraud et al. 2013), and clover (Swanepoel et al. 2011). In our study, the most promising native rhizobia isolated for the growth promotion effect in white clover plants was POA3. This rhizobia isolate improves the shoot and root dry matter and the amount of $\mathrm{N}$ accumulated in the shoots of white clover plants.

Our greenhouse experiments with white clover plants and rice in non sterile and sterile conditions demonstrated that there are rhizobia isolates that can improve the plant growth of both white clover and rice. The growth promotion effect of rice by the rhizobia inoculation has been reported by Biswas et al. (2000a, b). Antoun et al. (1998) reported that non-leguminous plants react to the presence of bradyrhizobia and rhizobia on their rhizospheres; however, the growth-promoting effect depended on the bacterial strains isolated and their endogenous PGP abilities (Galleguillos et al. 2000; Vessey 2003). In our study, the environment proved to be a very important component for plant growth promotion using rhizobia inoculation because several rhizobia isolates promoted the plant growth in sterile conditions, but they were unable to reproduce the same effect in non sterile, rich nutrient conditions (Table 6; Temprano et al. 2002; Bennett et al. 2003). This observation can be attributed to bacterial persistence and competition in the soil and to the amount of nutrients present in very rich soil conditions (Hagen et al. 1997; Krasova-Wade et al. 2006; Al-Khaliel 2010; Costa et al. 2013).

\section{Conclusion}

The native rhizobia nodulating white clover plants in southern Brazil is highly diverse. Some of the native rhizobia isolated in this work were able to improve the growth of both white clover and rice plants. This growth promotion effect in rice plants using rhizobia inoculation was more pronounced in a poor nutrient substrate environment than in a rich nutrient substrate environment.

In the future, it will be important to test the bacterial isolate POA3 in a field experiment with white clover and rice crop rotation to confirm its potential as a PGPR for both plants.

Acknowledgments This research was supported by grants and fellowships from the International Foundation for Science (IFS, Sweden), Fundação Estadual de Amparo à Pesquisa (FAPERGS, Brazil), Conselho 
Nacional de Desenvolvimento Científico e Tecnológico (CNPq, Brazil) and INCT da Fixação Biológica do Nitrogênio (Brazil).

\section{References}

Akers HA (1983) Isolation of the siderophore schizokinen from soil of rice fields. Appl Environ Microbiol 45:1704-6

Al-Khaliel AS (2010) Effects of arbuscular mycorrhization in sterile and non-sterile soils. Trop Life Sci Res 21:55-70

Altschul SF, Madden TL, Schaeffer AA, Zhang J, Zhang Z, Miller W, Lipman DJ (1997) Gapped BLAST and PSI-BLAST: a new generation of protein database search programs. Nucleic Acids Res 25:3389-3402

Alves AO, Xavier AS, Viana IO, Mariano RLR, Silveira EBS (2010) Colonization dynamics of Acidovorax citrulli in melon. Trop Plant Pathol 35:368-372

Ambrosini A, Beneduzi A, Stefanski T, Pinheiro FG, Vargas LK, Passaglia LMP (2012) Screening of plant growth promoting rhizobacteria isolated from sunflower (Helianthus annuus L.). Plant Soil 356:245-264

Antoun H, Beauchamp J, Goussard N, Chabot R, Lalande R (1998) Potential of Rhizobium and Bradyrhizobium species as plant growth promoting rhizobacteria on non-legumes: Effect on radishes (Raphanus sativus L.). Plant Soil 204:57-67

Arruda L, Beneduzi A, Martins A, Lisboa B, Lopes C, Bertolo F, Passaglia LMP, Vargas LK (2012) Screening of rhizobacteria isolated from maize (Zea mays L.) in Rio Grande do Sul State (South Brazil) and analysis of their potential to improve plant growth. Appl Soil Ecol 63:15-22

Ashraf MA, Asif M, Zaheer A, Malik A, Ali Q, Rasool M (2013) Plant growth promoting rhizobacteria and sustainable agriculture: a review. Afric J Microbiol Res 7:704-709

Beck D, Duc G (1991) Improving $\mathrm{N}_{2}$,-fixation in faba bean: Rhizobium inoculation and N nutrition. Opt Mediter 10:97-103

Bennett AJ, Leifert C, Whipps JM (2003) Survival of the biocontrol agents Coniothyrium minitans and Bacillus subtilis MBI 600 introduced into pasteurised, sterilised and non-sterile soils. Soil Biol Biochem 35:1565-1573

Binde DR, Menna P, Bangel EV, Barcellos FG, Hungria M (2009) repPCR fingerprinting and taxonomy based on the sequencing of the 16S rRNA gene of 54 elite commercial rhizobial strains. Appl Microbiol Biotechnol 83:897-908

Biswas JC, Ladha JK, Dazzo FB (2000a) Rhizobia inoculation improves nutrient uptake and growth of lowland rice. Soil Sci Soc Am J 64:1644-1650

Biswas JC, Ladha JK, Dazzo FB, Yanni YG, Rolfe BG (2000b) Rhizobial inoculation influences seedling vigor and yield of rice. Agronom J 92:880-886

Caballero-Mellado J, Martinez-Romero E (1999) Soil fertilization limits the genetic diversity of rhizobium in bean nodules. Symbiosis 26:771121

Chaparro JM, Sheflin AM, Manter DK, Vivanco JM (2012) Manipulating the soil microbiome to increase soil health and plant fertility. Biol Fertil Soils 48:489-499

Cho Y, Hidaka K, Mineta T (2003) Evaluation of white clover and rye grown in rotation with no-tilled rice. Field Crops Res 83:237-250

Chun J, Lee JH, Jung Y, Kim M, Kim S, Kim BK, Lim YW (2007) EzTaxon: a web-based tool for the identification of prokaryotes based on 16S ribosomal RNA gene sequences. Int J Syst Evol Microbiol 57:2259-2261

Costa PB, Beneduzi A, Souza R, Schoenfeld R, Vargas LK, Passaglia LMP (2013) The effects of different fertilization conditions on bacterial plant growth promoting traits: guidelines for directed bacterial prospection and testing. Plant Soil 368:267-280

Delgado MJ, Ligero F, Lluch C (1994) Effects of salt stress on growth and nitrogen fixation by pea, faba-bean, common bean and soybean plants. Soil Biol Biochem 26:371-376

Dubey RC, Maheshwari DK, Kumar H, Choure K (2010) Assessment of diversity and plant growth promoting attributes of rhizobia isolated from Cajanus cajan L. Afric J Biotech 9:8619-8629

Duodu S, Nsiah E, Bhuvaneswari T, Svenning M (2006) Genetic diversity of a natural population of Rhizobium leguminosarum biovar trifolii analysed from field nodules and by a plant infection technique. Soil Biol Biochem 38:1162-1165

Farina R, Beneduzi A, Ambrosini A, Campos SB, Lisboa BB, Wendisch V, Vargas LK, Passaglia LMP (2012) Diversity of plant growth-promoting rhizobacteria communities associated with the stages of canola growth. Appl Soil Ecol 55:44-52

Felske A, Rheims H, Wokerink A, Stackebrandt E, Akkermans DL (1997) Ribosome analysis reveals prominent activity of an uncultured member of the class Actinobacteria in grasslands soils. Microbiology 143:2983-2989

Ferreira MC, Andrade DDS, Maria L, Chueire DO, Takemura M, Hungria M (2000) Tillage method and crop rotation effects on the population sizes and diversity of bradyrhizobia nodulating soybean. Soil Biol Biochem 32:627-637

Galleguillos C, Aguirre C, Barea MJ, Azcón R (2000) Growth promoting effect of two Sinorhizobium meliloti strains (a wild type and its genetically modified derivative) on a non-legume plant species in specific interaction with two arbuscular mycorrhizal fungi. Plant Sci 159:57-63

Garbeva P, van Veen JA, van Elsas JD (2004) Microbial diversity in soil: selection microbial populations by plant and soil type and implications for disease suppressiveness. Ann Rev Phytopathol 42:243-70

Giller KE, Cadisch G (1995) Future benefits from biological nitrogen fixation: an ecological approach to agriculture. Plant Soil 174:255277

Giongo A, Ambrosini A, Vargas LK, Freire JRJ, Bodanese-Zanettini MH, Passaglia LMP (2008) Evaluation of genetic diversity of bradyrhizobia strains nodulating soybean [Glycine max (L.) Merrill] isolated from South Brazilian fields. App Soil Ecol 38:261-269

Giongo A, Beneduzi A, Ambrosini A, Vargas LK, Stroschein MR, Eltz FL, Bodanese-Zanettini MH, Passaglia LMP (2010) Isolation and characterization of two plant growth-promoting bacteria from the rhizoplane of a legume (Lupinus albescens) in sandy soil. R Bras C Solo 34:361-369

Giraud E, Xu L, Chaintreuil C, Gargani D, Gully D, Sadowsky MJ (2013) Photosynthetic Bradyrhizobium sp. strain ORS285 is capable of forming nitrogen-fixing root nodules on soybeans (Glycine max). Appl Environ Microbiol 79:2459-2462

Glickmann E, Dessaux Y (1995) A critical examination of the specificity of the Salkowski Reagent for indolic compounds produced by phytopathogenic bacteria. Appl Environ Microbiol 61:793-796

Hagen M, Alfred P, Selbitschka W (1997) The persistence of bioluminescent Rhizobium meliloti strains L1 (RecA) and L33 (RecA +) in non-sterile microcosms depends on the soil type, on the cocultivation of the host legume alfalfa and on the presence of an indigenous R. meliloti population. Plant Soil 188:257-266

Hall TA (1999) BioEdit: a user-friendly biological sequence alignment editor and analysis program for Windows 95/98/NT. Nucl Acids Symp Ser 41:95-98

Hammer O, Harper DAT, Ryan PD (2001) PAST: paleontological statistics software package for education and data analysis Version 2.09. Palaeont Electr 4(1):9

Handley B, Hedges AJ, Beringer JE (1998) Importance of host plants for detecting the population diversity of Rhizobium leguminosarum biovar viciae in soil. Soil Biol Biochem 30:241-249 
Hu X-J, Lin X, Wang J, Chu H, Yin R, Zhang J (2009) Population size and specific potential of $\mathrm{P}$-mineralizing and -solubilizing bacteria under long-term P-deficiency fertilization in a sandy loam soil. Pedobiologia 53:49-58

IRRI, AfricaRice, CIAT (2010). Global Rice Science Partnership (GRiSP). November 2010.

ISTA. International rules for seed testing. Seed Science and Technology. Zurich, 1996. 335 p.

Jonah N, Chemining'wa GN, Muthomi JW, Shibairo SI (2012) Effect of rhizobium inoculation and nitrogen fertilizer application on growth, nodulation and yield of two garden pea genotypes. J Anim Plant Sci $15: 2147-2156$

Kennedy AC (1999) Bacterial diversity in agroecosystems. Agricult Ecosyst Environ 74:65-76

Krasova-Wade T, Diouf O, Ndoye I, Sall CE, Braconnier S, Neyra M (2006) Water-condition effects on rhizobia competition for cowpea nodule occupancy. Afric J Biotech 5:1457-1463

Laheurte F, Berthelin J (1988) Effect of a phosphate solubilizing bacteria on maize growth and root exudation over four levels of labile phosphorus. Plant Soil 105:11-17

Ledgard SF (1991) Transfer of fixed nitrogen from white clover to associated grasses in swards grazed by dairy cows, estimated using ${ }^{15} \mathrm{~N}$ methods. Plant Soil 131:215-223

Ledgard SF, Steele KW (1992) Biological nitrogen fixation in mixed legume/grass pastures. Plant Soil 141:137-153

Li W, Raoult D, Fournier PE (2009) Bacterial strain typing in the genomic era. FEMS Microbiol Rev 33:892-916

Maguire JD (1962) Speed of germination - aid in selection and evaluation for seedling emergence and vigor. Crop Sci 2:176-177

Masson-Boivin C, Giraud E, Perret X, Batut J (2009) Establishing nitrogen-fixing symbiosis with legumes: how many rhizobium recipes? Trends Microbiol 17:458-466

Meliani A, Bensoltane A, Mederbel K (2012) Microbial diversity and abundance in soil: related to plant and soil type. Am J Plant Nutr Fert Tech 2:10-18

Menna P, Hungria M, Barcellos FG, Bangel EV, Hess PN, MartínezRomero E (2006) Molecular phylogeny based on the 16S rRNA gene of elite rhizobial strains used in Brazilian commercial inoculants. Syst Appl Microbiol 29:315-332

Mia MAB, Shamsuddin ZH (2010) Rhizobium as a crop enhancer and biofertilizer for increased cereal production. Afric $\mathrm{J}$ Biotech 9:6001-6009

Nannipieri P, Ascher J, Ceccherini MT, Landi L, Pietramellara G, Renella G (2003) Microbial diversity and soil functions. Europ J Soil Sci 54:655-670

Nesheim L, Boller BC (1991) Nitrogen fixation by white clover when competing with grasses at moderately low temperatures. Plant Soil 133:47-56

Peng S, BiswasJC LJK, Gyaneshwar P, Chen Y (2002) Influence of rhizobial inoculation on photosynthesis and grain yield of rice. Agronomy J 4:925-929

Prayitno J, Stefaniak J, Mciver J, Weinman JJ, Dazzo FB, Ladha JK, Barraquio W, Yanni YG, Rolfe BG (1999) Interactions of rice seedlings with bacteria isolated from rice roots. Aust J Plant Physiol 26:521-535

Raverkar KP, Konde BK (1988) Effect of Rhizobium and Azospirillum lipoferum inoculation on the nodulation, yield and nitrogen uptake of peanut cultivars. Plant Soil 106:249-252
Rodríguez H, Fraga R (1999) Phosphate solubilizing bacteria and their role in plant growth promotion. Biotech Adv 17:319-339

Sambrook J, Russel DW (2001) Molecular cloning: a laboratory manual. Cold Spring Harbor Laboratory Press, New York

Sarruge JR (1975) Soluções nutritivas. Summa Phytopathologica, Piracicaba 1(3):231-234

Schloter M, Wiehe W, Assmus B, Steindl H, Becke H, Höflich G, Hartmann A (1997) Root colonization of different plants by plant-growthpromoting Rhizobium leguminosarum bv. trifolii R39 studied with monospecific polyclonal antisera. Appl Environ Microbiol 63:20382046

Schwyn B, Neilands JB (1987) Universal chemical assay for the detection and determination of siderophores. Ann Biochem 160:47-56

Seck PA, Diagne A, Mohanty S, Wopereis MCS (2012) Crops that feed the world 7: rice. Food Sec 4:7-24

Shannon CE, Weaver W (1949) The mathematical theory of communication. University of Illinois Press, Urbana

Somasegaram P, Hoben MJ (1985) Methods in legume-rhizobium technology. NIFTAL, Hawaii, p 367

Souza R, Beneduzi A, Ambrosini A, Costa PB, Meyer J, Vargas LK, Schoenfeld R, Passaglia LMP (2012) The effect of plant growthpromoting rhizobacteria on the growth of rice (Oryza sativa L.) cropped in southern Brazilian fields. Plant Soil 366:585-603

Sparks DL (1996) Methods of soil analysis: chemical methods. SSSA Book Series, Madison, WI

Sundara B, Natarajan V, Hari K (2002) Influence of phosphorus solubilizing bacteria on the changes in soil available phosphorus and sugarcane and sugar yields. Field Crops Res 77:43-49

Swanepoel PA, Botha PR, Truter WF, Surridge-Talbot AK (2011) The effect of soil carbon on symbiotic nitrogen fixation and symbiotic Rhizobium populations in soil with Trifolium repens as host plant. Afric J Range For Sci 28:121-127

Temprano FJ, Albareda M, Camacho M, Daza A, Santamaria C, Nombre Rodriguez-Navarro D (2002) Survival of several Rhizobium/ Bradyrhizobium strains on different inoculant formulations and inoculated seeds. Int Microbiol 5:81-86

van der Heijden MGA, Bardgett RD, van Straalen NM (2008) The unseen majority: soil microbes as drivers of plant diversity and productivity in terrestrial ecosystems. Ecol Lett 11:296-310

Vargas LK, Lisboa BB, Schlindwein G, Granada CE, Giongo A, Beneduzi A, Passaglia LMP (2009) Occurrence of plant growthpromoting traits in clover-nodulating rhizobia strains isolated from different soils in Rio Grande do Sul state. Rev Bras C Solo 33:1227-1235

Versalovicj SM, Bruijn FJD, Lupski JR (1994) Genomic fingerprinting of bacteria using repetitive sequence-based polymerase chain reaction. Meth Mol Cel Biol 5:25-40

Vessey JK (2003) Plant growth promoting rhizobacteria as biofertilizers. Plant Soil 255:571-586

Wang F, Wang ET, Wu LJ, Sui XH, Li Y, Chen WX (2010) Rhizobium vallis sp. nov., isolated from nodules of three leguminous species. Intern $\mathrm{J}$ Syst Microbiol 62:2264-2271

Zhang X, Harper TR, Karsisto M, Lindstrom K (1991) Diversity of rhizobium bacteria isolated from the root nodules of leguminous trees. Intern J Syst Bact 41:104-113

Zahran HH (1999) Rhizobium-legume symbiosis and nitrogen fixation under severe conditions and in an arid climate. Microbiol Molec Biol Rev 63:968-989 